\title{
Effect of Communication Pattern on Agricultural Employees' Job Performance
}

\author{
Abiona, B.G. ${ }^{1} \quad$ Fakoya, E.O. $^{2} \quad$ Adeogun, S.O. ${ }^{1} \quad$ Blessed, J.O ${ }^{2}$ \\ 1.Department of Agricultural Administration, Federal University of Agriculture Abeokuta, P. M. B. 2240, Ogun \\ State, Nigeria \\ 2.Department of Agricultural Extension and Rural Development,Federal University of Agriculture Abeokuta, \\ P. M. B. 2240,Ogun State, Nigeria \\ dolace6ng@gmail.com
}

\begin{abstract}
This study assessed the influence of communication pattern on agricultural employees' job performance. Data were collected from 61 randomly selected respondents using a structured questionnaire. Perceived communication pattern that influence job performance include: attitude of the administrators $(\bar{x}=3.41$, physical barriers to communication flow among employees $(\bar{x}=3.21)$, poor communication reduces cooperation and teamworkof employees( $\bar{x}=3.12$ ) and wrong pattern of communication( $\bar{x}=3.06)$. Major challenges to respondents' job performance were different language among employees $(\bar{x}=3.12)$, employees perception on Organizational issues $(\bar{x}=3.09)$, networking $(\bar{x}=2.88)$ and unclear definition of work $(\bar{x}=2.74)$. A significant relationship was found between employees' perceived communication pattern $(\mathrm{r}=0.423, \mathrm{p}<0.00)$ and job performance. Information must be well designed in such a way that would positively influence employees' job performance as this is essential in any agricultural organizations.
\end{abstract}

Keywords: Communication pattern, job performance and agricultural employees

\subsection{Introduction}

An organization is established when a group of people are working together to achieve a goal. There are various kinds of organization with different pattern of working and with different set of goals for instance Corporation, Government, Non-governmental Organization, International Organization, Cooperatives, Universities and various types of political organizations. In any organization, there are always a board of committees or the decision makers and the subordinate. There must be an effective way of communication between the two groups within an organization

Communication is the transfer of information from one person to the others. Communication may be intentional or unintentional, conventional or unconventional signals. It may also take linguistic or non-linguistic forms and may occur through a specific mode. (Julia Scherba,1992).

Communication between employees and their employers can prevent all forms of counterproductive behaviours. In general terms, communication can be described as a process which conveys information between people (Rollinson 1993). Ineffective or inadequate communication or flow can quickly lead to speculations and rumors.

However, irrespective of the mode, once there is a smooth and well defined information flow among members which allow effective feed-back from the receiver so that organizational objectives will be achieved without any problem.Communication between employees is also important in the achievement of organizational goals (A. Simon, 1947). Campbell (1990) suggested that one of the determinants of job performance is the knowledge of the facts and ideas of organizational aims and objectives. This study therefore tends to ascertain the influence of communication pattern on job performance of staff of National Center for Genetic Research and Biotechnology, Ibadan, Oyo State, Nigeria. The specific objectives were to:

i. examine the personal characteristics of the employees.

ii. determine the perceived effect of communication pattern on job performance among the respondents.

iii. ascertain the level of job performance of the respondents.

iv. identify various challenges faced by the employees of the National Center for Genetic Research and Biotechnology in the study area.

\section{Hypotheses}

$\mathrm{Ho}_{\mathrm{i}}$ There is no significant relationship between respondents' personal characteristics and their job performance.

$\mathrm{Ho}_{\mathrm{ii}}$ There is no significant relationship between communication pattern and their job performance.

$\mathrm{Ho}_{\mathrm{iii}}$ There is no significant relationship between barriers to communication and employees job performance. 


\subsection{Methodology}

This study was carried out at the National Center for Genetic Research and Biotechnology, Ibadan, Oyo State, Nigeria. This Institute was established in 1967. The Institute is located opposite Moor Plantation, along Apata Road in Ibadan, Oyo State, Nigeria. It was established and founded by the Federal Government of Nigeria with a view to ensure improvement in production level of food and cash crops and to ensure that Nigeria benefit from the potential of the biotechnology research.

The data for the study were obtained using a structured questionnaire. The questionnaire was structured into sections to generate information about personal characteristics using frequency and percentages. Perceived effect of communication pattern of the respondents and job performance were measured using a likert scale: strongly agree $=4$, agree $=3$, disagree $=2$ and strongly disagree $=1$. Communication barriers to job performance was measured using a 4 - point likert scale of very often $=4$, often $=3$, rarely $=2$ and not at all $=1$. Descriptive and inferential statistics were used for data analysis. Descriptive statistics included frequencies, percentages, mean and standard deviation. Chi square and Pearson Product Moment Correlation were used to determine commutation pattern and job performance of the respondents.

\subsection{RESULTS AND DISCUSSION}

\subsection{Personal characteristics of respondents}

Table 1 shows the personal characteristics of the respondents. Less than half $(47.5 \%)$ of the respondents were between the age bracket of 28-37years. Less than half (31.2\%) of the respondents were in the age bracket of 3847 years. Result revealed that, $14.8 \%$ of the staff was between the ages of 48-57 years. The implication of these findings is that there were more vibrant, active and energetic people between the ages of 28 - 40 years in the study area. This observation agrees with findings of Isaac (2011) and FAO (1997) whose reported revealed that agricultural employees in the South Western part of Nigeria were in the age range of 30-40 years. Similarly, Oso (2010) also reported that most $(55.02 \%)$ of the researchers in Oyo State were in the age range of $31-40$ years. It can be inferred from this result that many of the researchers are still within the economic active and productive age and will therefore be able to adequately carry out their research work.

Sex is an important factor to consider in any organization. Based on this, most (52.5\%) of the respondents were male while $41.0 \%$ were female indicating that male employees were more than the female in the studied organization. This trend is understandable considering the technicality and nature of the operations of the organization. This result suggests that females are involved in research work but not as compared to their male counterpart. This result agrees with the findings of Oso (2010), Dunn, (1995) and Ladebo (2003) who reported that there were more male researchers in Oyo State than their female counterpart. It was revealed that $68.9 \%$ of the respondents were married, while less than half $(26.2 \%)$ was single. This agrees with the findings of Banmeke (2012) who reported that there were more married researchers in research Institutes found in Nigeria.

Table 1: Personal characteristics of the respondents $n=61$

\begin{tabular}{lccc}
\hline Variables & Frequencies & Percentages & Means \\
\hline Age(years) & 6 & 9.8 & 32.5 \\
$18-27$ & 27 & 47.5 & 24.6 \\
$28-37$ & 15 & 18.2 & \\
$38-47$ & 11 & 52.5 & \\
48 and above & & 41.0 & \\
Gender & 32 & & \\
Male & 25 & 26.2 & \\
Female & & 68.9 & \\
Marital status & 19 & 67.2 \\
Single & 42 & 29.5 & \\
Married & & & \\
Educational qualification & 41 & & \\
HND/Bsc & 18 & \\
Msc/PhD &
\end{tabular}

Source: Field survey, 2014

\subsection{Respondents' perceived effect of communication pattern that affects their job performance}

Table 2 shows respondents' perceived effect of communication pattern on job performance. The result shows that the major perceived effects of communication pattern that affect their job performance were: poor communication affect organizational goals $(\bar{x}=3.14)$, poor communication reduces cooperation and teamwork among employees $(\bar{x}=3.12)$. The implication of this result is that continuous flows of communication among 
staff will help them to perform a given task and achieve their goals timely. The result also shows that if communication is not well patterned it will reduce employees performance $(x=3.06)$. This finding is line with the report of Malone and Crowston (1994) that reaching consensus is rather better than imposing decision which could enhance job performance.

Table 2 Respondents' perceived effect of communication pattern that affect their job performance $(n=61)$

\begin{tabular}{|c|c|c|c|c|c|}
\hline $\begin{array}{l}\text { Perceived effect of communication } \\
\text { pattern }\end{array}$ & $\mathbf{S A}$ & $\mathbf{A}$ & $\mathbf{D}$ & SD & $x$ \\
\hline It reduces cooperation and teamwork & $30(49.2)$ & $12(19.7)$ & $15(24.6)$ & $4(6.6)$ & 3.12 \\
\hline It reduces group cohesion & $18(29.5)$ & $28(45.9)$ & $4(6.6)$ & $10(16.4)$ & 2.85 \\
\hline It results in dishonesty to the organization & $14(23.0)$ & $23(37.7)$ & $11(18.0)$ & $13(21.3)$ & 2.62 \\
\hline $\begin{array}{l}\text { It shifts attention from other meaningful } \\
\text { task }\end{array}$ & $14(23.0)$ & $24(39.3)$ & $6(9.8)$ & $17(27.9)$ & 2.58 \\
\hline It affect organizational goals & $36(59.0)$ & $9(14.8)$ & $5(8.2)$ & $11(18.0)$ & 3.14 \\
\hline It reduces workers performances & $28(45.9)$ & $17(27.9)$ & $7(11.5)$ & $9(14.8)$ & 3.06 \\
\hline $\begin{array}{l}\text { It waste resources (human, time and } \\
\text { money) }\end{array}$ & $14(23.0)$ & $17(27.9)$ & $22(36.1)$ & $8(13.1)$ & 2.61 \\
\hline It reduces employees productivity & $30(49.2)$ & $12(19.7)$ & $6(9.8)$ & $13(21.3)$ & 2.97 \\
\hline It leads to job dissatisfaction & $24(39.3)$ & $14(23.0)$ & $7(11.5)$ & $16(26.2)$ & 2.75 \\
\hline $\begin{array}{l}\text { It reduces mutual understanding among } \\
\text { employees }\end{array}$ & $27(44.3)$ & $17(27.90$ & 7911.5) & $10(16.4)$ & 3.00 \\
\hline $\begin{array}{l}\text { It reduces communication flow among } \\
\text { employees }\end{array}$ & $22(36.1)$ & $20(32.8)$ & $9(14.8)$ & $9(14.8)$ & 2.87 \\
\hline It develops various attitudinal problems & $7(11.5)$ & $19(31.1)$ & $13(21.3)$ & $21(34.4)$ & 2.16 \\
\hline $\begin{array}{l}\text { Good communication } \\
\text { cooperation and teamwork }\end{array}$ & $51(83.6)$ & $7(11.5)$ & $2(3.3)$ & - & 3.75 \\
\hline $\begin{array}{l}\text { It improves coordination among } \\
\text { employees }\end{array}$ & $41(67.2)$ & $19(31.1)$ & - & $1(1.6)$ & 3.64 \\
\hline It increases organizational productivity & $38(62.3)$ & $22(36.1)$ & ---- & ---- & 3.60 \\
\hline It improves quality of decision making & $31(50.8)$ & $22(36.1)$ & $5(8.2)$ & $2(3.3)$ & 3.30 \\
\hline $\begin{array}{l}\text { It promote spirit of acceptability among } \\
\text { employees }\end{array}$ & $34(55.7)$ & $24(39.3)$ & $1(1.6)$ & $1(1.6)$ & 3.46 \\
\hline
\end{tabular}

\section{Source: Field survey, 2014}

Note: $\mathrm{S} . \mathrm{A}=$ Strongly Agree, $\mathrm{A}=$ Agree, $\mathrm{D}=$ Disagree, $\mathrm{S} . \mathrm{D}=$ Strongly Disagree, $\bar{x}==$ Mean, $\mathrm{S} . \mathrm{D}=$ Standard Deviation.

\subsection{Respondents' perception of job performance}

Table 3 shows respondents' perception of job performance. The result reveals that most of the administrators' attitude play a critical roles in the upward communication $(x=3.45)$. This result is in line with Anderson and martin (1995) who reported that employees sought communication interaction with superior to satisfy interpersonal needs of pleasure and inclusion. Based on this, time lag between communication inhibit employees job performance $\left(\bar{x}_{=}=3.08\right)$. Similarly, employees were not satisfied with their job due to poor communication ( $x=3.69)$. This findings corroborated the report of Rubin(1993) that when employees needs are met through satisfying communication, they are likely to build effective work relationship. Employees feel discontented with their job due to status problems $\left({ }^{x}=2.98\right)$ which was another indicator identified during the course of study. This result is in line with the findings of Gbadamosi and Nwosu (2011) who reported that job satisfaction is very potent predictor of organizational commitment among researchers. 
Table 3 Respondents' perception of job performance

\begin{tabular}{llllll}
\hline Job performance & SA & A & D & SD & Means \\
\hline $\begin{array}{l}\text { I feel discontented with my job due to ego } \\
\text { problems }\end{array}$ & $24(39.3)$ & $23(27.7)$ & $3(4.90$ & $11(18.0)$ & 2.98 \\
$\begin{array}{l}\text { employees were not satisfied with their } \\
\text { job due to poor communication }\end{array}$ & $43(70.5)$ & $17(27.9)$ & $1(1.6)$ & --- & 3.69 \\
$\begin{array}{l}\text { time lag between communication inhibit } \\
\begin{array}{l}\text { employees job performance } \\
\text { administrators attitude plays a critical }\end{array} \\
\begin{array}{l}\text { roles in the upward communication } \\
\text { Soln }\end{array}\end{array}$ & $30(49.2)$ & $29(46.1)$ & $1(1.6)$ & $8(13.1)$ & 3.08 \\
\end{tabular}

Source: Field survey, 2014

Figures in parenthesis are percentages

Note: $\mathrm{S} . \mathrm{A}=$ Strongly Agree, $\mathrm{A}=$ Agree, $\mathrm{D}=$ Disagree, $\mathrm{S} . \mathrm{D}=$ Strongly Disagree, $\bar{x}=$ Mean, S.D $=$ Standard Deviation.

\subsection{Respondents' communication barriers that affecting their job performance.}

Table 4 shows respondents views on the major communication barriers to their job performance. Result shows that language barriers $(\bar{x}=3.12)$ was the major challenge affecting job performance of the employees. This finding indicates that respondents in the study are from various ethnic groups, uses of local language could distort information which may affect the level of job performance. The second major barriers affecting job performance was employees perception on organizational issues $(x=3.01)$.especially when they do not have full information about the funding pattern of the organization Okoro (2000). Among other challenges identified were Inadequate communication network $(\bar{x}=2.88)$. This result is supported by Rollinson (1993) who was of the opinion that inadequate communication can lead to speculation and rumor which will affect employees job performance. Lack of confidence in subordinate $(x=2.87)$ and insufficient on the job training $(x=2.67)$. This is in line with the findings of Jex (2002) who reported that employees who is poorly trained or lack ability to perform well will affect the achievement of organizational goals.

Table 4 Communication barriers affecting employees job performance $(n=61)$

\begin{tabular}{llllll}
\hline Barriers & SA & A & D & SD & Means \\
\hline $\begin{array}{l}\text { language barriers } \\
\text { employees perception on organizational }\end{array}$ & $30(49.2)$ & $18(29.5)$ & $4(9.8)$ & $12(19.7)$ & 3.12 \\
issues & $24(39.3)$ & $23(37.7)$ & $5(8.2)$ & $9(14.80$ & 3.01 \\
Inadequate communication network & $23(37.7)$ & $20(32.8)$ & $7(11.5)$ & $10(16.2)$ & 2.88 \\
Lack of confidence in subordinate & $18(29.5)$ & $27(44.3)$ & $6(9.8)$ & $10(16.4)$ & 2.87 \\
Defective coding & $16(26.2)$ & $13(21.3)$ & $15(24.6)$ & $16(26.2)$ & 2.44 \\
Insufficient on the job training & $18(29.5)$ & $20(32.8)$ & $8(13.1)$ & $15(24.6)$ & 2.67 \\
Timing of work & $20(32.8)$ & $22(36.1)$ & $6(9.8)$ & $12(19.7)$ & 2.79 \\
\hline
\end{tabular}

Source: Field survey, 2014

Figures in parenthesis are percentages

Note: S.A= Strongly Agree, $\mathrm{A}=$ Agree, $\mathrm{D}=$ Disagree, $\mathrm{S} . \mathrm{D}=$ Strongly Disagree, $\bar{x}=$ Mean, S.D $=$ Standard Deviation.

\section{5: Relationship between perceived effect of communication pattern and job performance}

A significant relationship exists between communication pattern and job performance $\left(r=0.423^{*}, p<0.05\right)$. This result is in line with the assertion of $\mathrm{Ng}$ et al, 2006 who suggested that increased job performance with communication in the organization will result into an increased performance of employees. In other word communication pattern could influence job performance among staff of any organization.

Table 5: Relationship between communication pattern and job performance

\begin{tabular}{llll}
\hline Variable & R & p-Value & Decision \\
\hline Communication pattern and job performance & 0.423 & 0.00 & $\mathrm{~S}$
\end{tabular}

Source: Field Survey 2014

P-Value is Significant at 0.05 level of significance 


\subsection{Relationship between challenges faced by employees and their job performance.}

Table 6 presents the relationship between communication barriers faced by staff and their job performance. A positive and significant relationship was found between language barriers $(\mathrm{r}=62.44, \mathrm{P}<0.05)$, employees perception on organizational issues $(\mathrm{r}=76.05, \mathrm{p}<0.05)$, Inadequate communication network $(\mathrm{r}=66.7, \mathrm{p}=0.05)$, lack of confidence in subordinate $(\mathrm{r}=57.61, \mathrm{p}=0.05)$, defective coding $(56.38, \mathrm{p}=0.05)$, and timing of work ( $\mathrm{r}=54.97, \mathrm{p}<0.05$ ) faced by staff and their job performance. This implies that challenges encounter by the employees may affect the attainment of the organizational goals.

Table 6: Relationship between respondents' challenges and job performance

\begin{tabular}{|c|c|c|c|}
\hline Variable & $\mathbf{R}$ & p-Value & Decision \\
\hline Language barriers & 62.44 & 0.01 & $\mathrm{~S}$ \\
\hline $\begin{array}{l}\text { Employees perception on } \\
\text { organizational issues }\end{array}$ & 76.05 & 0.00 & $\mathrm{~S}$ \\
\hline $\begin{array}{l}\text { Inadequate } \\
\text { communication network }\end{array}$ & 66.27 & 0.04 & $\mathrm{~S}$ \\
\hline $\begin{array}{l}\text { lack of confidence in } \\
\text { subordinate }\end{array}$ & 57.61 & 0.02 & $\mathrm{~S}$ \\
\hline defective coding & 56.38 & 0.03 & S \\
\hline Timing of work & 54.97 & 0.04 & S \\
\hline
\end{tabular}

Source: Field Survey 2014

P-Value is Significant at 0.05 level of significance

\section{CONCLUSION AND RECOMMENDATIONS}

Communication pattern had a strong role to play on staff performance in any organization. It was concluded from the study that communication must be patterned in such way that it will be accommodating, work friendly and also influence the productivity of the employees.

Based on the findings of this study, the following recommendations are suggested:

1) The role of job performance cannot be over emphasized therefore communication must be channeled in such way that it will be of use to staff development in any organizations.

2) Manager should identify an effective communication pattern that can be of help in motivating their employees in other to give out their best.

3) Managers in the organization should make sure that communication channels are stream lined, focusing on employee participation, linking compensation with performance; ensuring that just decision making procedures are in place.

\section{References}

Anderson, C.M. and Martin, M.M. (1995).The effects of communication motives, interaction, involvement, and Loneliness on Satisfaction: A Model of small groups. Small Group Research, 26, 118-137

Banmeke, T.O.A. (2012). Assessment of usage of Social Network tools Among Agricultural researchers in South western. Nigeria.Journal of Extension Systems, 19(2): 34-44

Campbell, J.P. (1990) Modeling the performance prediction problem in industrial and organizational psychology. In M.D. dunnatte \& L. M. Hough (Eds), handbook of Industrial and Organizational Psychology pp687-732. Palo Alto, CA: Consulting Psychologist Press, Inc.

Gbadamosi, L. \& Nwosu, C. J. (2011). Entrepreneurial Intention, Organizational justice and job Satisfaction as determinants of Employees organizational Commitment: Evidence from Babcock University Nigeria. Proceedings of Information Science \& IT Education Conference, 205-211

FAO, (1997). Review of the state of World Aquaculture. FAO Fisheries Cir. 886 (Rev.1)

Herbert A Simon.(1947) A study of decision processes on Administrative Organization. Free Press ISBN10:0684835827.pp 310

Hugh, R.R. (1993) Using Geochemical Evaluation, Presentation and Interpretation, Longman, Edinburgh Gate. ISBN0-582-06701-4.pp 352

Issac, B.O (2011). Information and Communication Technology as drivers of growth: experience for selected scale producer in rural south west. Ibadan, Nigeria.

Jex, S.M. (2000). Organization Psychology: A Scientist-Practitioner approach, new York, NY:John Wiley\& Sons.Inc

J.S. de Valenzuela, "National Joint Committee for the Communicative needs of persons with Severe Disabilities,"1992.

Malone, T.W. and Crowston, K. (1994). The interdisciplinary of coordination. Computing Surveys. 26(1), 87119 
Ng, W.H.T., Butts, M.M., Vandenberg, R. J., DeJoy, d.M.\& Wilson, M.G. (2006). Effect of management communication, opportunity for learning for learning and work schedule flexibility on organizational commitment. Journal of Vocational Behaviour, 68 474-489.

Ladebo, O. J (2003). Organizational Commitment as a Predictor of Job Performance among Faculty: Implication for Development of Agricultural Technology in Nigeria. Journal of International Agriculture and Extension Education, 10(3): 57-64

Oso, O. A. (2010). Effects of communication satisfaction on researchers work-attitudes in selected agricultural research institutes in Oyo State, Nigeria. UnpublishedM.Agric. Thesis submitted to the Department of Agricultural Extension and Rural Development, University of Agriculture, Abeokuta, Nigeria.

Rubin, A.M.(1993) The effects of locus of control on communication motives anxiety and satisfaction. Communication quarterly, 41. (162-17) 
The IISTE is a pioneer in the Open-Access hosting service and academic event management. The aim of the firm is Accelerating Global Knowledge Sharing.

More information about the firm can be found on the homepage:

http://www.iiste.org

\section{CALL FOR JOURNAL PAPERS}

There are more than 30 peer-reviewed academic journals hosted under the hosting platform.

Prospective authors of journals can find the submission instruction on the following page: http://www.iiste.org/journals/ All the journals articles are available online to the readers all over the world without financial, legal, or technical barriers other than those inseparable from gaining access to the internet itself. Paper version of the journals is also available upon request of readers and authors.

\section{MORE RESOURCES}

Book publication information: http://www.iiste.org/book/

Academic conference: http://www.iiste.org/conference/upcoming-conferences-call-for-paper/

\section{IISTE Knowledge Sharing Partners}

EBSCO, Index Copernicus, Ulrich's Periodicals Directory, JournalTOCS, PKP Open Archives Harvester, Bielefeld Academic Search Engine, Elektronische Zeitschriftenbibliothek EZB, Open J-Gate, OCLC WorldCat, Universe Digtial Library, NewJour, Google Scholar

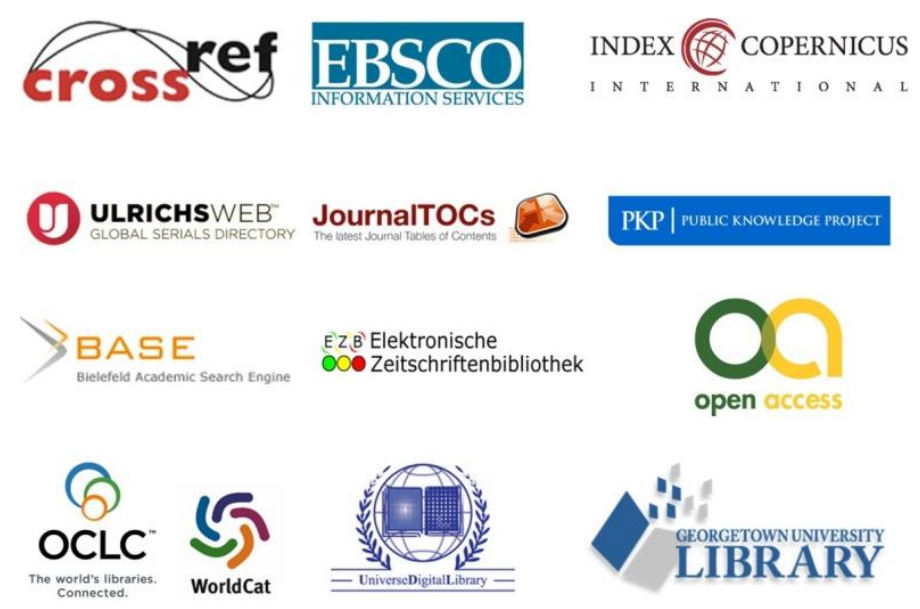

